\title{
Paratransit Difa Bike As An Innovation Of Economy Empowering and Accessibility for Difabel
}

\author{
Riska Melinda Hutari \\ Politik Pemerintahan, Universitas Gadjah Mada, Yogyakarta, Indonesia
}

\begin{abstract}
Difa Bike is one of the innovations in the field of transportation of Paratransit and a kind of online motorcycle taxi, but the difference is that both the driver and the customer are people with disabilities. In carrying out its services Difa Bike uses a lot of internet technology. Economic empowerment is the main objective of the establishment of Difa Bike so that people with disabilities are not entangled in the cycle of poverty. The accessibility aspect is also present in the service both for drivers and customers.
\end{abstract}

Keywords: Difa Bike, Paratransit, Accessibility, Difabel

\section{Research Background}

This paper discusses the innovation related to the economic empowerment of disabled groups as well as the presence of accessibility in it. The innovations that occur cannot be separated from the role of advances in information and communication technology that is currently developing rapidly. The greatest technological revolution at this time, later known as the 4.0 revolution (Kazancoglu and OzkanOzen 2017). The strong influence of technology has brought many changes in all areas ranging from business-economy to governance. The importance of this paper is to see the extent to which the diffable can fill the economic sector by utilizing developing technologies to improve their welfare, accessibility and independence. Disability groups can be said to be marginal groups that are reticent towards discrimination.

* Corresponding author: Riska Melinda Hutari

riskamelindaa@gmail.com

Published online at http://IJDS.ub.ac.id/

Copyright @ 2019PSLD UB Publishing. All Rights Reserved

${ }^{1}$ Tempo.Co Baru 1 Persen Teman Disabilitas yang bekerja di Sektor Formal. Diakses pada tanggal 9

Oktober 2019 pukul 10.30
One form of discrimination is in the process of finding employment.

Data published by Sakernas (2016) shows that persons with disabilities in Indonesia, aged 15 years and over, amounted to 22.8 million people or around $12.15 \%$. while those with severe disabilities are $1.87 \%$ and those with mild disabilities are $10.29 \%$. The highest number of persons with disabilities is in the provinces of West Java, East Java and Central Java. Looking at the data above, the number of persons with disabilities who are minorities compared to and non persons with disabilities allows discrimination in various sectors. While the compulsory system data reports the Ministry of Manpower, the employment of disabled workers has only been around 2,851 or around $1 \%$ placed in the formal sector. ${ }^{1}$.

The large workforce of people with disabilities that have not been absorbed in the formal sector should receive more attention from the government to formulate appropriate policies 
in encouraging the labor market for people with disabilities. The current attention of the government has indeed experienced this development. It can be seen from the existence of Law No. 8 of 2016 concerning Persons with Disabilities, which requires the obligation to employ persons with disabilities with a portion of $1 \%$ for companies and $2 \%$ for BUMN / BUMD. Various training and supplies were also provided by the Social Service to empower disabled groups. However, the disparity between workers with disabilities and non-disabled people is still very large, referring to the report of the ministry of labor.

The various data exposure above is a general description that with the number of minority persons with disabilities in Indonesia, in fact, entering the formal workforce is still very difficult. The provision of training and training conducted by related agencies also did not have a significant impact. However, the existence of the 4.0 revolution can now be captured as a golden opportunity for people with disabilities to improve their welfare and economic independence. The development of internet technology that is included in various fields including industry can help them to find and open new jobs. The real impact of this revolution is felt strongly, for example on online ticket reservations, online hotels, buying and selling online and so on. Therefore, it is important to see how the diffable can innovate economic empowerment as well as the presence of accessibility in it.

\section{Theoretical Review}

Referring to Law No. 8 of 2016 concerning Persons with Disabilities, guaranteeing continuity or the same rights and obligations for people with disabilities. Article 11 of Law No. 8 of 2016 regulates the right to work, entrepreneurship and cooperatives for persons with disabilities including the right to obtain work organized by the Government, Regional
Government, or the private sector without discrimination. Not only getting a job, but this law also regulates the right to promote business, entrepreneurship, cooperative development, and start your own business. This regulation then opens opportunities for people with disabilities to develop themselves in various employment sectors. One sector of employment is in the field of transportation. Transportation has various types, one of which is paratransit.

\subsection{Paratransit}

Informal paratransit or transportation is a mode of transportation whose services are provided by operators and can be used by anyone with an agreement between passengers and riders Hartshern (1992). Paratransit emerged in developing and developed countries. The causes of paratransit appearance according to Britton (1979) include:

1. Change of a city

2. There is a closer relationship between transportation and land use

3. The inability of the city to provide public public transportation with $100 \%$ service

4. There are limited services by formal public transportation.

Developing countries like Indonesia, possess forms of paratransit such as bicycles, rickshaws, horse carts and so on. The characteristics of paratransit in developing countries Cervero (2007) and Susantono (2002) are as follows:

1. Informal transportation has certain market segments. The emergence of demand in this market segment is because formal transport is unable to serve it. therefore the informal role of transportation becomes a gap fill in the need for transportation in an area.

2. Informal transport drivers in fact operate in a system that approaches a free market where competition and entrepreneurship are prominent factors 
3. Informal transport operators will be very helpful in providing better services

4. Safety aspects (helmets, belts, etc.)

\subsection{Accsessbility}

Making parantransit certainly must pay attention to various aspects, one of which is accessibility for drivers and customers. Accessibility is the equivalent of availability (availability) so access and availability cannot be separated. Access is the ability of people to find and get services. Service accessibility is the level of adjustment between the characteristics of resources and the community in the process of seeking and obtaining services (Frank, 1992).

The principles of accessibility according to the Decree of the Minister of General Work of the Republic of Indonesia Number: 468 / Kpts / 1998 include:

A. Ease: i.e. everyone can reach all places or buildings that are common in an environment.

B. Usability: that is, everyone must be able to use all the places or buildings that are common in an environment.

C. Safety: that is, every building which is general in a built environment, must pay attention to the safety of all people.

D. Independence: that is, everyone uses all the places or buildings that are common in an environment without the need for help from others

\section{Research Method}

This study aims to see how the disabled can fill the economic sector by utilizing developing technologies to improve their welfare, accessibility and independence. the type of research used by researchers is qualitative research. Qualitative research is research that uses a natural setting with the intention of interpreting phenomena that occur and is carried out by involving various existing methods ${ }^{2}$. Writing format is to use a qualitative descriptive format. Qualitative descriptive aims to describe, summarize the various conditions, situations or phenomena of social reality that exist in society that are the object of research. Writing format is to use a qualitative descriptive format. Qualitative descriptive aims to describe, summarize the various conditions, situations or phenomena of social reality that exist in society that are the object of research ${ }^{3}$. This is because the data collected is in the form of words and images. The data comes from interview scripts, field notes, photographs, personal documentation, notes or memos and other official documents ${ }^{4}$.

This research was conducted at Difa City our and Travel Office Jl. Srikaloka Jl. Bugisan No.5A, Patangpuluhan, Wirobrajan, Yogyakarta City, Special Region of Yogyakarta. The main data sources in qualitative research are words and the complete actions are additional data such as documents and so on. Primary data or data obtained directly from the data sources so that the actual data obtained directly on the object of research. Primary data in this study were obtained through direct interviews with informants. The speakers included Difa Bike Founder, Difa Bike Manager, 3 Difa Bike drivers and 3 Difa Bike customers. Difa Bike Driers are mostly physically challenged, while Difa Bike customers come from various disabilities, such as hearing impairment, disability, blindness and cerebral palsy. Secondary data or data that includes additional material that comes from written sources. Written sources are divided into sources of scientific books and magazines, sources from archives, personal documents and

\footnotetext{
2 Moelong, 2008. Meode Penelitian Kualitatif. Bandung : PT Remaja Rosdakarya
}

${ }^{3}$ Bungin, Burhan 2008. Penelitian Kualitatif : Komunikasi, Ekonomi, Kebijakan Publik, dan IImu Sosial lainnya. Jakarta : Kencana

${ }^{4}$ Moelong, loc.cit 
official documents. Data collection techniques in the form of interviews and observations.

\section{Results and Discussion}

\subsection{Paratransit Difa Bike As An Inovation Of} Economy Empowering

\subsubsection{Difa Bike as a Form of Paratransit}

The initial idea of the formation of Difa Bike was initiated by Triyono who was a person with disabilities in 2015, starting with the refusal to become an online motorcycle taxi driver. The refusal to become a driver is also not based on the SOP written on the online motorcycle taxi. Triyono then created the idea of a motorcycle taxi or three-wheeled motorcycle, where the rider and the customer are disabled. Difa Bike operating system is almost the same as an online motorcycle taxi through the application. Customers can use Difa Bike services not only limited to the application but can be via WhatsApp, website or SMS and telephone. Difa Bike only had one vehicle at the beginning, with trial and error and grants from CSR and other donors to modify according to the driver, eventually increasing to three vehicles and three drivers. To find and recruit drivers is done by visiting groups with disabilities. Dissemination to customers is also the same when recruiting drivers, namely socialization to disabled organizations in each district in Yogyakarta.

"saya tanpa malu mbak, dari satu organisasi difabel ke organisasi lainnya sambil bawa pamflet, brosur untuk memperkenalkan Difa Bike ini seharian, padahal saya juga perlu untuk mencari nafkah untuk kebutuhan saya"5

The cost to modify a vehicle requires approximately seven million rupiahs, not including motorbikes which cost approximately fourteen million rupiahs. From the Difa Bike office only helps to modify, while the motorbike belongs to the driver himself. Difa Bike was officially inaugurated on International Disability Day which was held in Yogyakarta City Hall. Currently Difa Bike has 25 drivers and 5 office administrators. Difa Bike vehicle development is carried out by collaborating with technical faculties such as UST.

The emergence of paratransit is nothing new in developing and developed countries. as said by Hartshen (1992) explains that the mode of transportation of paratransit services is provided by the operator and can be used by anyone with an agreement between the passenger and the rider. This opinion is then clarified by the opinion of F.E.K Briton (1979) who said that paratransit is multi-modal in the transportation system to serve certain places and in accordance with certain market needs or known as informal intermediaries in transit, semi-public, unincorprated and non conventional. If you look at the Difa Bike case, it can be said that this mode of transportation falls into the paratransit category. when analyzed why this Difa Bike paratransit can be formed as expressed by Britton (1979) regarding the emergence of paratransit in developing and developed countries, among others, as follows :

First the change of a city, transportation is now increasing in number along with the needs of human mobility so high that Yogyakarta is no exception. Various types of public transportation emerged and provided various services. Not only non-disabled people who need mobility, but people with disabilities also need mobility to carry out their activities. Changes in the amount of transportation, mobility needs, road terrain that changes due to road widening and so on are what then drives the emergence of paratransit. Second, the inability of the city to provide public public transportation with $100 \%$ service. Public transportation is not completely disabilityfriendly.

\footnotetext{
${ }^{5}$ wawancara dengan Founder Difa Bike tanggal 8 Oktober 2019 pukul 12.15
}

Cite this as:

Hutari, Riska Melinda. Paratransit Difa Bike As An Innovation Of Economy Empowering and Accessibility for Difabel .Indonesian Journal of Disability Studies (IJDS).2019: Vol. 6(2): PP 230 - 239 
"saya pernah mau naik angkutan umum mbak, menunggu lama sekali sampai ada yang mau mengangkut saya, kalau teman saya malah harus ganjel pintu angkutan umum pakai kruk kakinya dulu baru diangkut" 6

The above statement proves that it is still difficult to be friendly to disability, even though there are still some public transportation that is friendly to disability. This has become one of the drivers of the emergence of Difa Bike to help the mobility of people with disabilities. Third, there are limited services by formal public transportation. The initial idea in making this Difa Bike was to fulfill the mobility needs of people with disabilities, which these needs could not be met by other formal transportation. Difa Bike Tagline itself is the world's first disabled online transportation ${ }^{7}$. Difa bike modification in the form of motorcycle taxi or the first threewheeled motorcycle in the world with the specific purpose of accommodating persons with disabilities with disability drivers.



Fig 1. Difa Bike with the Driver

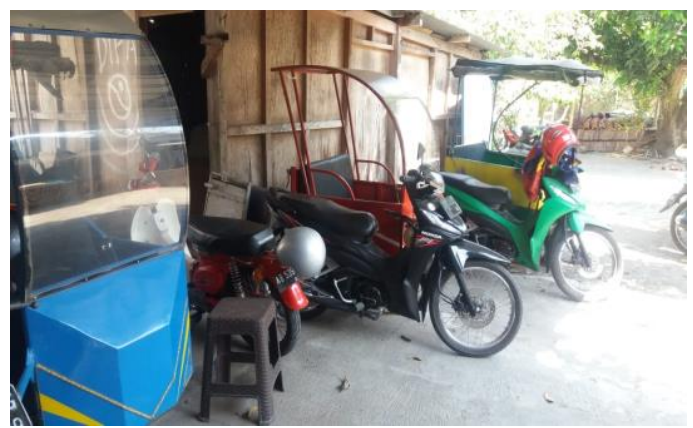

\footnotetext{
${ }^{6}$ wawancara dengan salah satu Driver Difa Bike tanggal 8 Oktober 2019 pukul 14.00
}

Cite this as:

Hutari, Riska Melinda. Paratransit Difa Bike As An Innovation Of Economy Empowering and Accessibility for Difabel .Indonesian Journal of Disability Studies (IJDS).2019: Vol. 6(2): PP 230 - 239
Fig 2. Parking condition of Difa Bike

Difa bike is still limited to serving on certain routes, and has not been spread throughout the city of Yogyakarta. Difa Bike route has been determined by the Founder, so that drivers and customers can definitely choose which route to go. Here is a list of route regions and some Difa Bike services.

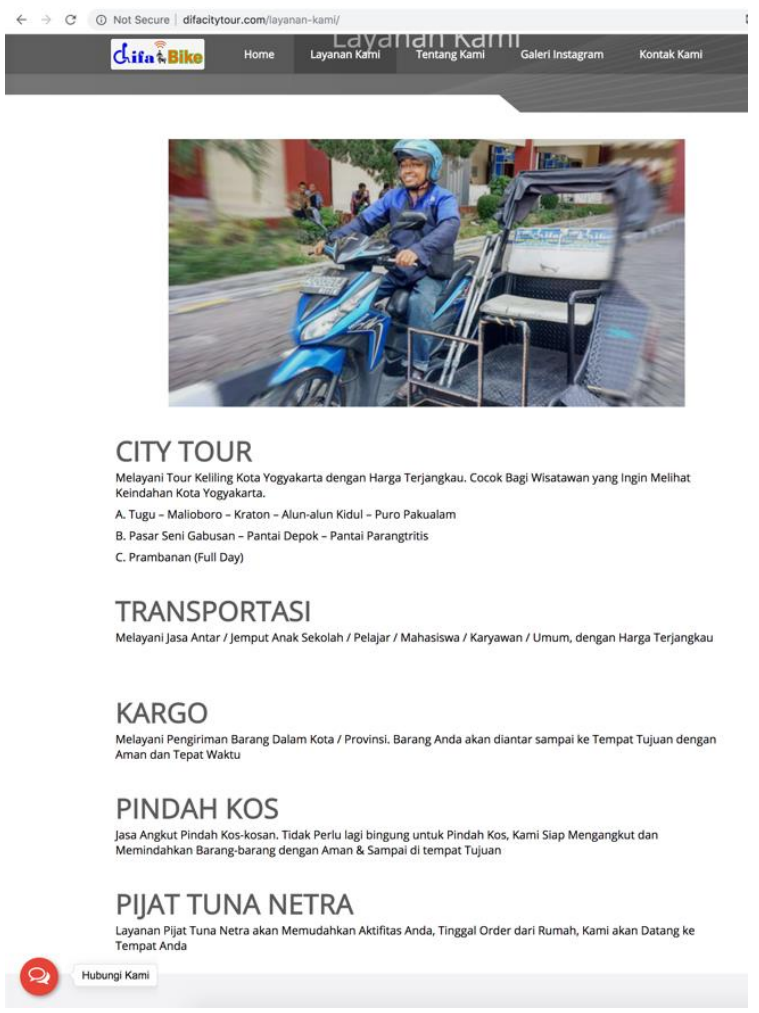

Fig 3. Website of Difa Bike

\subsubsection{An Impact of Difa Bike as Independence Economic for Difabel}

The development of disability discrimination issues in various sectors continues to spread. For the founder of Difa Bike, the source of the problem is inmobility. Inability and no guarantees of movement make the sharpness of

${ }^{7}$ wawancara dengan Manajer Difa Bike tanggal 8 Oktober 2019 pukul 13.15 
discrimination against the disabled. Starting from this background, the idea of making a modified three-wheeled vehicle. Making the entire fleet to date about 200-250 million for developing, fleet and operations. To determine the tariff, Difa Bike made a cooperation agreement whereby 70 for riders and 30 for Difa Bike offices. The tariff breakdown can be seen as follows:

- $\quad$ Layanan Transport Rp 20.000/5 Km awal, over $5 \mathrm{Km}$ tarif Rp 2.500/km

- City Tour :

- Tugu-Malioboro-Aloon aloonPuro Pakualam Rp 100.000 time limit 4 hour.

- Pasar Seni Gabusan-Puro Depok-Parangtritir Rp 200.000 Full day

- Borobudur-Mendut Rp 250.000 Full Day

- City Tour Pilihan pelanggan sendiri / tematik Rp 100.000 time limit 4 hour.

- Kargo < $50 \mathrm{~kg} \mathrm{Rp} \mathrm{20.000/5} \mathrm{Km} \mathrm{awal,}$ over $5 \mathrm{Km}$ tarif $\mathrm{Rp} 2500 / \mathrm{km}$

- Massage (Sleman, Kota Yogyakarta, Bantul) Rp 80.000/jam

- Difa Care (free shuttle to hospitals, health centers, and other health services for people with disabilities who are poor)

From this tariff, revenue sharing for transportation services, City Tour and cargo will be determined at $70 \%$ for drivers and $30 \%$ for offices. Whereas $50 \%$ for Massage for the Blind, $40 \%$ for drivers and $10 \%$ for offices.

"kalau mereka dapat 100ribu, kemudian setor 60ribu yasudah tidak kita tarik lagi, itulah bedanya socialenterprise kita memikirkan mereka dan profitenterprise setor ya setor. Difa bike roh dari empowering and bussiness center for disability bukan pusat rehabilitasi.
Mengempowering dan bisnis center harapannya bukan hanya trnsportasi tapi juga tentang edukasi, pelan-pelan saya masukkan pendidikan informal, seperti jahit, bordir, bahasa, sablon dan sebaainya"

Difabike does not want to be only profit oriented as described above, but also strives to foster the diffable to be economically independent. Therefore a variety of informal training is given so that they have other skills. Not only at this time, but before recruiting drivers there is some training for three months given, among others:

- Introduction to location of tourism

- Riding a special motorcycle

- Raising and lowering passengers

- Public Speaking management training

- Assist in arranging SIM D (specifically for disabilities)

- English Language Training

The criteria for becoming a driver, of course, are those with disabilities (mild or moderate physical disabilities), come from disadvantaged families, have a KTP Yogyakarta, and have a minimum of primary school education and have a D SIM.

"Dulu saya penggembala itik di sawah, kemudian pada perkumpulan disabilitas di Kecamatan ada mas Tri. Lantas saya daftar menjadi driver dan dilatih, saya senang bekerja disini alhamdulillah kebutuhan saya tercukupi punya banyak teman yang muda-muda karena dulu saya tidak punya teman",

Driver's income per day is an average of $\mathrm{Rp}$. 60,000 - Rp. 100,000, if crowded can reach Rp. 200.00. While Difa Bike's income is Rp 120,000 - Rp 150,000 per day. For expenses per month around Rp. 7,000,000 per month. To manage finances and cover costs Difa Bike has a number of donor funds deposited in banks, so that they

\footnotetext{
${ }^{9}$ wawancara dengan Driver $\mathrm{G}$ yang merupakan tuna

daksa pada tanggal 8 Oktober 2019 pukul 14.00

Cite this as:

Hutari, Riska Melinda. Paratransit Difa Bike As An Innovation Of Economy Empowering and Accessibility for Difabel .Indonesian Journal of Disability Studies (IJDS).2019: Vol. 6(2): PP 230 - 239 
can be collected at any time if there are unforeseen expenses. Mobility from one place to another becomes its own entertainment for drivers. They feel more understanding themselves. For them the economy is second, while the first is how they can survive. To be heard by others is something that makes them feel light. Motivation can be one input for the next government agenda, so it's not just training and debriefing. The development of Difa bike as a business center that is not only centered on transportation but on other economic development certainly requires support from various parties.

"saat ini pengendara memang utamanya adalah driver tapi ada beberapa dari mereka yang memiliki usaha sampingan seperti bordir, menurut saya ini adalah bentuk kemandirian dan empowering" 10

Almost the same as other online motorcycle taxi systems, Difa Bike also applies sanctions and rewards. Sanctions are given if the driver refuses to take the passenger in the form of a negative point award. It also provides recommendations to customers so as not to use the drier, so drivers will be quiet customers. Drivers who at will will also be confiscated for several days by Difa Bika so that they feel deterrent, if they do not change the cooperation agreement will be terminated. While the reward is given to drivers who are diligent and in the form of incentives.

\subsection{Accsessbility Difa Bike}

\subsubsection{Ease}

Vehicle Difa Bike was deliberately designed according to the needs of customers with disabilities. Data from the Yogyakarta Social Service shows that the number of persons with disabilities in 2017 was 29,530. With details of the distribution of persons with disabilities in Kulon Progo of 5,775, Bantul 6,525, Gunung Kidul 8,594, Sleman 6,669 and Yogyakarta 1,967. The existence of Difa Bike can make it easy for people with disabilities, although the Difa Bike route is still limited in Sleman Yogyakarta and Bantul. To order transportation services simply by using technological sophistication that can be through applications, websites, whatsapp, telephone or sms. After ordering, the driver will immediately go to the pickup point. Modifications to this motorcycle taxi or three-wheeled motorcycle are indeed adapted to people with disabilities (visually impaired, physically disabled, wheelchair users, and other people with disabilities.

"saya senang mbak, naik Difa Bike karena bisa langsung di depan rumah tidak perlu kemana mana lagi. Selain itu juga tidak panas karena ada tenda penutupnya" ${ }^{\prime \prime}$

For persons with disabilities, the Blind Difa Bike can assist them in mobilizing. No need to go far to find public transportation, they just need to wait in front of the house and transfer to their destination. For wheelchair users, the wheelchair can be folded and placed in a Difa Bike vehicle, making it easy to sit in the vehicle.

\subsubsection{Usability}

Difa Bike vehicles are considered to be very useful for providing services for the disabled. When public transportation cannot fully accommodate persons with disabilities to carry out activities, Difa abike appears and provides services to these needs. Difa Bike Development continues to be done so that it is better in providing services. As we can see the picture below is one of the Difa bike vehicle projects which is expected to provide better benefits for customers and drivers. In the future, it is expected that drivers will only need to press

\footnotetext{
${ }^{10}$ wawancara wawancara dengan Founder Difa Bike pada tanggal 8 Oktober pukul 12.20

${ }^{11}$ wawancara dengan pelanggan Difa Bike Tuna Netra pada tanggal 9 Oktober pukul 10.00

Cite this as: 
the buttons and the vehicle will reverse itself like a car.



Fig 3. Future Difa Bike Design

\subsubsection{Safety}

Difa Bike deliberately designed by considering the safety aspects. There are seat belts for wheelchairs so that when they start driving, the wheelchair does not shake or even harm passengers. There is also an SNI helmet so that passengers are better protected. For drivers, Difa Bike adjusts modifications according to the driver, for example changing the gas handle to the left for automatic motors. Move the brakes in the hand, the footrests are stretched or raised according to the driver. One vehicle is only intended and used for 1 driver.

\subsubsection{Independence}

The independence of Difa Bike drivers can be demonstrated when raising and lowering disabled passengers. This independence is trained when the training period becomes a driver, drivers practice raising and lowering disabled passengers with various categories, for example blind, Daksa, and cerebal palsy. Independence is not only felt for drivers but also

Cite this as:

Hutari, Riska Melinda. Paratransit Difa Bike As An Innovation Of Economy Empowering and Accessibility for Difabel .Indonesian Journal of Disability Studies (IJDS).2019: Vol. 6(2): PP 230 - 239 customers. Customers can mobility with a little help from others. Can go to the destination with or without other people. The existence of Difa Bike certainly gives birth to various benefits for persons with disabilities.

\section{Conclusion}

The presence of Difa Bike as an economic empowerment innovation for people with disabilities is the impact of the progress of information and communication technology. Amid the rise of online motorcycle taxis as an alternative to overcoming traffic congestion, inspiring a person with a disability to participate in opening jobs in the field of transportation namely "Difa Bike" with the primary goal of empowering people with disabilities as drivers while providing accessibility for customers who are also disabled. Like online ojeg in general, Difa Bike utilizes internet technology in its service. Difa Bike can be categorized as a mode of paratransit transportation, where informal transportation has a certain market segment in this case persons with disabilities. The most prominent factor driving the emergence of paratransit is the inability of formal transportation to provide one hundred percent service for persons with disabilities. Therefore Difa Bike can be referred to as alternative transportation and fill the gap of transportation needs, especially for persons with disabilities.

In terms of economic empowerment, especially for Difa bike drivers with the calculation of profit sharing rates between Difa Bike offices and Drivers of $70 \%$ for drivers and $30 \%$ of offices are expected to provide hope for a better future. Economic empowerment is also done by providing training before becoming a driver and after becoming a driver. The training included English courses, embroidery, sewing and screen printing. Although they are expected to be a driver they also have a side business so that it can increase their daily needs. Whereas in terms of accessibility, Difa Bike provides accessibility for both motorists and customers, namely first, ease, the spread of persons with 
disabilities in several districts in Yogyakarta and their limited mobility makes Difa Bike a paratransit transportation that makes it easy for them to do mobility by simply waiting ahead home. Second, safety, safety aspects are always emphasized both for drivers and customers. So as to minimize accidents. Thirdly, Difa Bike is certainly very useful and becomes a gap filler where public transportation cannot provide maximum services for persons with disabilities. Fourth of independence, for drivers of independence can be seen from not dependent on others, drivers can find the necessities of life and do it independently. While customers can independently carry out activities to a place, without relying on others.

\section{References}

Access Exchange Internasional. 2012. Paratransit For Mobility Impained Persons in Developing Regions : Startingup \& Scallingup GUide. San Fransisco : AEI

Black A. 1995. Urban Mess Transport Planning. Singapore : Mc Graw Hill Book co.

Britton F.E.K. 1979. The Two worlds of Paratransit : Service Innovations \& New Planning App for Eighties. Unpublished paper at the Bureau of Transport Economics \& Director - General of Transport South Australia Paratransit Workshop Mount Gambier.

Bungin, Burhan. 2008. Penelitian Kualitatif : Komunikasi, Ekonomi, Kebijakan Publik, dan Ilmu Sosial lainnya. Jakarta : Kencana

Cervero, Robert. 2007. Informal Transportation : A Global Perspective. Transport Policy 14 : $445-447$

Matthew B Miles \& A. Michael Huberman. 1992. Analisis data Kualitatif Buku Sumber tentang metode-metode baru. UI
Moelong. 2008. Metode Penelitian Kualitatif. Bandung : PT. Remaja Rosdakarya

Regulasi :

Keputusan Menteri Pekerjaan Umum No. 468/KPTS/1998

Undang-Undang No. 8 Tahun 2016 Tentang Penyandang Disabilitas

Interview :

Wawancara dengan Triyono, Founder Difa City Tour and Travel

Wawancara dengan Manajer, Difa City Tour and Travel

Wawancara dengan G, Disabilitas daksa (tangan layu) Driver Difa City Tour and Travel

Wawancara dengan YS, Kaki diamputasi karena terlindas kayu Driver Difa City Tour and Travel

Wawancara dengan TH, Disabilitas daksa Driver Difa City Tour and Travel

Wawancara dengan S, Penumpang Penyandang disabilitas netra Difa City Tour and Travel

Wawancara dengan FT, Penumpang Penyandang disabilitas daksa Difa City Tour and Travel

Wawancara dengan ST, Penumpang Penyandang disabilitas netra Difa City Tour and Travel

Website :

Rini Kustiani, "Baru 1 Persen Teman Disabilitas yang Bekerja di Sektor Formal", https://difabel.tempo.co/read/1143835/baru-1persen-teman-disabilitas-yang-bekerja-disektor-formal, diakses pada tanggal 9 Oktober 2019 Pukul 10.30 